International Journal of English Language Studies (IJELS)

ISSN: $2707-7578$

DOI: $10.32996 /$ ijels

Website: https://al-kindipublisher.com/index.php/ijels

\title{
Traumatic Experiences and their Representation in Narratives: A Study
}

\author{
Dharmapada Jena ${ }^{1} \square$ and Prof. Kalyani Samantray ${ }^{2}$ \\ ${ }^{1}$ Research Scholar, Utkal University, Bhubaneswar, Odisha, India \\ ${ }^{2}$ Professor \& HoD, Faculty of Arts, Communication and Indic Studies, Sri Sri University, Bhubaneswar, Odisha, India
}

$\square$ Corresponding Author: Dharmapada Jena, E-mail: dharmapada2009@gmail.com

\begin{tabular}{ll}
\hline ARTICLE INFORMATION ABSTRACT \\
\hline
\end{tabular}

Received: 08 October 2021

Accepted: 25 October 2021

Published: 10 November 2021

DOI: 10.32996/ijels.2021.3.11.1

\section{KEYWORDS}

Traumatic experiences, representation, narrative tools, strategies for representation
With the rise of psychiatric literature and medical humanities, trauma studies have gained significant focus in recent years. The studies that were done by Kidd (2005), Perring (2013),_Olive (2014), Seran (2015), Tembo (2017), Hussain et al. (2018), Finck (2006), Durrant (2012), Long (2012), De Mey (2012), Curtis (2015), Karpasitis (2010), Ward (2008) and Dauksaite (2013), particularly, deal with diverse traumatic experiences. At the same time, they also throw light on the issues of the representation of trauma in narratives. They have examined narrative strategies, like the use of transgenerational empathy, intermediality of text and image, syntax disruption, ellipses, text/image layout, repetitions, symbols, photograph insertion, and assimilation, intertexts, framing of panels, inter-textuality, repetition, fragmentation, and flashback, that can be employed to deal with the challenges for the representation of traumatic experiences in narratives. This paper argues that the narrative features and techniques embedded in the narratives can be utilized for the representation and understanding of diverse traumatic experiences. The narrative components like plot (event), character and theme can be analyzed to discuss the psychological trauma of different characters. Researches can also rely on narrative techniques like flashbacks, flashforward, frame story, events in parallel, narrative shift, multi-perspectivity, repetitive designation, epiphany, amplification, imagery, tone, use of repetitive sentence structure, hamartia, peripetia, and comparison to examine how these techniques help represent the psychological trauma of the characters in the narratives.

\section{Introduction}

"Trauma," originally referred to as "wound" (Marder, 2006, p. 1) or more specifically as physical injury or damage, has now come to be viewed as a distressing and disturbing experience that overwhelms one's life. This psychological connotation of the term "trauma" lends it wide acceptance in the medical and psychiatric literature in particular, and literature in general. In all the cases, the studies on trauma essentially focus on understanding and interpreting traumatic experiences. The issues of the representation of traumatic experiences have also been the focus of recent studies.

Many researchers (Tal (1995); Caruth (1996); Rogers (2004); Ward (2008); Whitehead (2011) and Heidarizadeh (2015)) have engaged with the difficulties involved in the representation of traumatic experiences in narratives. They believe that the belated and indirect access to the traumatic past poses challenges for its representation. It is also argued that traumatic experiences are difficult to be represented for these "fragment consciousness and prevent direct linguistic representation" (Caruth, 1996, p. 4). This paper will closely analyze some of the researches based on traumatic experiences and the issues of their representation in narratives. It will particularly discuss how the researchers deal with the challenges of representing traumatic experiences. The narrative tools and strategies explored by the researchers will also be the focus of this paper.

\section{Representation of Traumatic Experiences}

Copyright: (C) 2021 the Author(s). This article is an open access article distributed under the terms and conditions of the Creative Commons Attribution (CC-BY) 4.0 license (https://creativecommons.org/licenses/by/4.0/). Published by Al-Kindi Centre for Research and Development, London, United Kingdom. 
Kidd (2005) discusses the representation of traumatic experiences in Holocaust narratives, where young adult protagonists suffer from and witness to trauma. He discusses Roberto Innocenti's picture book Rose Blanche (1985), Seymour Rossel's The Holocaust (1981), and Jane Yolen's novel The Devil's Arithmetic (1988) to explore the protagonists' direct experiences of the Holocaust. He takes on the recent young adult novels about genocidal trauma and the picture books about 9/11 to discuss the evidence of trauma testimony. Perring (2013)_examines texts on childhood abuse to discuss how they address the issues of blame and resentment. He evaluates the role of excuses and forgiveness of the traumatized towards their traumatizers. He has discussed the novels and memoirs that exclusively deal with abusive or neglectful parents, caregivers, or guardians. Perring argues that family turns to be a site for difficulty, abuse, and trauma. He deals with books that feature abuses and traumatic experiences. Dave Pelzer's A Child Called "It" (1995) and Maria Landon's Daddy's Little Earner (2008) disclose the shocking story of child abuse by parents. The theme of sexual abuse is presented in Silenced (2009) of Vicky Jaggers and Tears at Bedtime (2007) by Tom Wilson and Andrew Crofts. All these books witness "pain of the abuse, the horrendous behavior of the abusers, the vulnerability of children and the strength of children to overcome the abuse" (Perring, 2013, p. 4). Perring also takes some_literary memoirs like_Tiger, Tiger: A Memoir (2011) by Margaux Fragoso and Running with Scissors (2002) by Augustan Burroughs that also deal with the theme of sexual abuse which might be classified as traumatic. Perring argues that all the victims of abuse_in these memoirs and novels managed to recover from their trauma. Olive (2014) reads Amitav Ghosh's The Calcutta Chromosome (1995) through the lens of trauma studies and explores how it represents internal postcolonial conflicts. She argues that "The Calcutta Chromosome represents postcolonial identity as traumatic through a comprehensive analysis of the various thematic and structural levels" (Olive, 2014, p. 9). She views the novel as a "manifestation of postcolonial trauma" (Olive, 2014, p. 62). Olive brings forth the conflicting histories in the postcolonial situation as she discusses the novel. The plot of the novel revolves around discovering the badge of Murugan, a missing employee. "Antar spends the rest of the novel using Ava as a means of finding out what happened to Murugan after he went to Calcutta and what Murugan hoped to find there" (Olive, 2014, p. 7).

Like Perring (2013),_Seran (2015) switches to autobiographical writings. She studies the connection between life-writing and trauma through Sally Morgan's My Place (1987), a Stolen Generations narrative that centers around the plight and testimony of the Stolen Generations, a large group of mixed-descent children forcibly removed at great distances from their Aboriginal families and raised to fit into white society. She argues that the novel depicts the issues of child removal in the Aboriginal context, and discusses the inherited traumas of it. The protagonist, Morgan, and her family experience a transgenerational trauma of child removal. Tembo (2017) explores the depiction of civil war in East African fictional and autobiographical works published between 2000 and 2014. He examines the various ways in which East African writers use literature and art to represent the physical, emotional, and psychological trauma caused due to intra-state conflicts in East African states like Ethiopia, Eritrea, Rwanda, Somalia, South Sudan, Sudan, and Uganda. Tembo holds here a study on twelve literary texts taken from different states of East Africa; predominantly dealing with intra-state conflicts and various traumatic experiences on that account. Tembo argues that "[e]ach of the selected texts either depicts a collective trauma, which is explored from a personal point of view or focuses solely on a personal experience of trauma" (Tembo, 2017, p. 3). Texts like Halima Bashir's Tears of the Desert (2009), Rupert Bazambanza's Smile through the Tears (2007), Cristina Ali Farah's Little Mother (2011), Marie Béatrice Umutesi's Surviving the Slaughter (2004), China Keitetsi's Child Soldier (2002), Emmanuel Jal's War Child (2009), Senait Mehari's Heart of Fire (2006) and Leah Chishugi's A Long Way from Paradise (2010) discuss the personal experiences of public trauma. On the other hand, Dinaw Mengestu's All Our Names (2014), Maaza Mengiste's Beneath Lion's Gaze (2010), Nadifa Mohamed's The Orchard of Lost Souls (2014), and Goretti Kyomuhendo's Waiting (2007) represent collective traumatic experiences. All these texts, Tembo goes on to say, "offer an insightful range of reflections on the trauma of civil war experienced by survivors, perpetrators, children, child soldiers, rape victims, immigrants, and refugees, among others" (Tembo, 2017, p.3).

The research by Hussain et al. (2018) explores the selected short stories that feature the suffering of women, their dilemma, and trauma during partition. They argue that women were the worst sufferer in the tragedy of the partition. They were "abducted and subjected to sexual savagery" (Hussain et al., 2018, p. 585). Hussain et al. explore the theme of the trauma and survival of a helpless old woman in Mulk Raj Anand's "The Parrot in the Cage" (2006). They argue that "[t]he Partition uprooted, dispossessed, and displaced millions of people, turned them into refugees overnight, and reduced them to a state of confusion, panic, and anguish" (Hussain et al., 2018, p. 586). Finck (2006) discusses the traumatic events such as the enslavement of Africans in the United States or the attempted extermination of the Jewish people in Europe. This study involves the trilogy by postmodern French artist Charlotte Delbo, an Auschwitz survivor who narrated her story in testimonial form, offers that insight into trauma, as does the postcolonial work of Toni Morrison. Durrant (2012) argues that tragedy enables a traumatized body of people to survive the phenomenal erosion of time that constitutes the precipitate experience of colonization. It projects the Igbo of Nigeria as a terrifying example of the engulfment which can suddenly overtake a people within a trauma of helplessness. Long (2012) explores some of the prehistories of contemporary trauma theory from the ruins of what might anachronistically be called early modern psychology. Specifically, this research examines early modern casuistical literature-religious writings about conscience-to show that much of what is now discussed in psychiatric and scientific circles concerning trauma once belonged to a different lexical territory, literature about the soul. Rogers (2004) studies the representation of trauma in six late twentieth century novels: Ceremony (1977) 
by Leslie Marmon Silko; Beloved (1987) by Toni Morrison; Margaret Laurence's The Diviners (1974); Lives of Girls and Women (1971) by Alice Munro; Michele Roberts' Daughters of the House (1992) and The Sea, The Sea (1978) by Iris Murdoch. Through these novels, she examines debates about trauma and narrative. Rogers argues that "the relationship between narrative and trauma is paradoxical: a narrative is an essential tool for bearing witness to the trauma, but it can also intentionally or unintentionally be used to create an inauthentic version of events" (Rogers, 2004, p. ii). This relationship of trauma and narrative creates a space for developing a narrative form that is able to effectively represent trauma. The novels, she analyses, strive to find an effective means of representing trauma. All these novels depict their protagonists "suffering the consequences of trauma" and how they "try to evade their respective traumas by creating illusory versions of the events" (Rogers, 2004, p. 11). She also discusses how these novels offer their protagonists "the opportunity of working through their traumas by developing new interpretative strategies" (Rogers, 2004, p. 11). Rogers observes that all the novels under discussion depict either "collective trauma" or "personal trauma," narrated from a personal point of view (Rogers, 2004, p. 2). Ward (2008) explores the relationship between writing and traumatic events. At the outset, he discusses trauma theory and situates it in the scheme of holocaust narratives. He explores the inherent problem of writing the past memories of the holocaust and the "gap in time and experience negotiated in narratives that deal with events from previous generations" (Ward, 2008, p. 5). De Mey (2012) discusses the representation of both first-hand and intergenerational trauma in the novels: Awake in the Dark (2006) and The Listener (2009) by the Jewish-Australian author, Shira Nayman. In the beginning, De Mey discusses trauma theory to show how traumas of the first generation are represented with regard to the characteristics of the second and third generations of Holocaust survivors. Curtis (2015) studies postcolonial Irish fictions to find how these narrate traumatic memories. She discusses the growing number of accusations of abuse and mistreatment against the clergy in the Catholic community in Ireland and how these lead to the decline of the influence of the church. She mentions that "with every allegation, victims found themselves returned to the scenes of trauma. The spaces where they should have found protection and care were once again sources of anxiety and fear instead" (Curtis, 2015, p. 3). The memories of abuse and trauma of the victims are quite ignored for long and often subjected to a lengthy process of investigations. "What emerges from these investigations is a nation confronted with memories of abuse and trauma that had been institutionally misrepresented in order to maintain the facade of irreproachable, postcolonial, moral identity..." (Curtis, 2015, p. 3). This scenario calls for urgency to study the representation of trauma in Irish literature. The relevance of trauma studies as an important tool for representing and understanding trauma in the context of Irish literature is examined. She opines that trauma studies meet certain limitations with "psychoanalytical understanding of the trauma that it does not fully encompass an important aspect of the cultural context of Irish literature" (Curtis, 2015, p. 5). She examines how despite this limitation trauma studies manage to negotiate in response to traumatic events in the narratives. She discusses three texts: The Secret Scripture (2008), Reading in the Dark (1996), and The Gathering (2007) and examines how trauma is being represented. She also explores how the events of the past continue to haunt the present. She argues that Sebastian Barry's The Secret Scripture (2008) uses the mode of alternating narration which is one of the "main issues of testimony, authority over the 'truth'" (Curtis, 2015, p. 8). The alternating narration happens between Roseanne, who is determined to write out her life's history, and Dr. Grene, the attending Psychiatrist of the hospital.

\section{Strategies for Representation}

All the researchers have employed some sort of strategies to tackle the difficulties in representing traumatic experiences. Kidd (2005), for instance, examines contemporary trauma theory and explores how it deals with personal trauma instead of political. He examines the interdependence of psychoanalysis and forms of trauma and at the same time questions their testimonial equivalence as asserted by contemporary trauma theory. He argues that testimonial evidence makes "trauma more personal than political" (Kidd, 2005, p.124). Olive (2014) examines the use of metaphors and their related functions of personification and metonymy to represent trauma and thus create a ground to understanding "the novel as a metaphoric representation of trauma" (Olive, 2014, p. 10). She relies on Caruth's "traumatic aporia" and "Gérard Genette's structuralist methodology of analyzing narrative discourse" to bring about the various manifestations of postcolonial traumatic experiences (Olive, 2014, pp. 88, 91). Seran (2015) finds "[t]he complexity of representation in literary practice functions as a challenge to colonial boundaries and allows for the possible coexistence of past and present as contained in the time of writing" (Seran, 2015, p. 664).

Tembo (2017) uses the features of postcolonial criticism and trauma studies in order to discuss the nature of violence in the East African context. He examines postcolonial concepts like hybridity, displacement, enunciation, identity formation, ambivalence, alterity, and otherness. Through these postcolonial features, he tends to present the "postcolonial realities" as often characterized as "displacement and/or migration caused by violence" (Tembo, 2017, p. 157). He also uses the principles of trauma studies provided by Cathy Caruth (1995), Shoshana Felman (1992), Dori Laub (1992), Dominick LaCapra (2001), and others for the discussion of trauma in postcolonial East African contexts. He utilizes concepts like "the uncanny," and "latency" for the portrayal of the traumatized individuals, groups, and communities (Tembo, 2017, pp. 16, 17). In connection to remembering and forgetting the Rwandan genocides, Tembo utilizes Bakhtin's notion of "the chronotope" (Tembo, 2017, p. 27). According to Bakhtin "the chronotope" can be defined as "the intrinsic connectedness" of time and space in literary texts ("Dialogic" 84). Karpasitis (2010) addresses one of the under-examined areas of literary trauma theory: that of recovery and reconnection of the survivor following a traumatic event. As such this research proposes that Milton's construction of Satan in Paradise Lost (1674), can be read from a 
survivor empowerment standpoint. Moreover, that Satan in this instance follows to a significant degree, the stages for a successful recovery from trauma.

Ward (2008) goes a step ahead to argue that a narrative strategy "transgenerational empathy", an approach to the past that is self-reflexive, can be used to assemble the ideas of time, memory, and generations (Ward, 2008, p. 58). Here he draws upon Dominick LaCapra's definitions of empathy and "empathic unsettlement", and on Hans-Georg Gadamer's concept of the "fusion of horizons" between past and present (Ward, 2008, p. 58). The term "empathic unsettlement" can be viewed as something that "involves a kind of virtual experience through which one puts oneself in the other's position while recognizing the difference of that position and hence not taking the other's place" (Ward, 2008, p. 58). The research then discusses the model of proximity and distance that highlights the disputed relation between memory and history. It "situates Binjamin Wilkomirski's false memoir Fragments (1995) and Anne Michaels' poetic novel Fugitive Pieces (1996) in the context of the memory/history debate" (6). Ward argues that Wilkomirski and Michaels' texts over-privilege memory. They "merely identify rather than empathize with the Holocaust victims they depict" (Ward, 2008, p. 6). Here, memory is associated with effect, identification, and proximity whereas history aligns with intellect, objectivity, and distance. Thus, memory and history seem to be operating in two opposite ways. The work by Ward (2008), in short, has explored some possible avenues into transgenerational empathy as a narrative strategy. It has brought into discussion the use of personae in the narrative, the traumatic past, and the concept of post-memory. The narrative representation of the Holocaust has also remained one of its main focuses.

Dauksaite (2013) discusses some of the most common techniques and means of representation of trauma as used by Vladas Kalvaitis in his novel Sustiprinto režimo barakas (2011). She examines the relationship between fiction and trauma and finds that both use "means of repetition, fragmentation and a lack of chronology" (Dauksaite, 2013, p. 2545). Based on this observation, she tends to negotiate Sustiprinto režimo barakas (2011) as a trauma fiction. Dauksaite begins her discussion with a reference to Anne Whitehead who believes that "trauma fiction is related to post-modern and postcolonial literature and borrows certain means of representation from them" (Dauksaite, 2013, p. 2545). She examines how trauma fictions help understand colonial traumas such as forced migration, sexual, racial, and political violence, and so on. The experiences of such traumas however do follow actual chronology while being represented. She thus states "traumatic stories in fiction become fragmented" (Dauksaite, 2013, p. 2546). However, writers try to convey trauma in a realistic way by imitating reality. Dauksaite in this research explores the literary techniques and means of representation in trauma fiction. For such exploration, she embarks on the view of other researchers like Baelo-Allue (2012) who states trauma fictions use intertextuality, repetition, and fragmentation as a narrative technique. They also use images to represent trauma and Arizti (2011) believes that they use fragmentary memories or fragmentary narratives. They use other techniques like incoherence, flashbacks, and digressions and at times they too use topographic features like dashes and suspension points. Arizti (2011) also believes that they generate tension between remembering and forgetting. According to Vickroy (2002), narrative techniques like textual gaps (both in the page layout and content, repetition, breaks in linear time, shifting viewpoints, and a focus on visual images and affective states are common in trauma fiction.

Curtis (2015) here examines the role of memory in such transmission. She finds that the narrator is burdened with "postmemory" and continues to communicate past trauma that "leaves community wounds raw, interrupting the cycle of transmission" (Curtis, 2015, p. 36). The final text, Anne Enright's The Gathering (2007) "utilizes frequent forays into both an imagined past and the unreliable memories of the narrator's childhood" (Curtis, 2015, p. 10). The writer presents here "uncertain" memory and tries to reach an "authentic" memory (Curtis, 2015, p. 42). The narrator, Veronica is possessed by the trauma of her brother's death. "The trauma of her brother's death initiates a profound disruption of Veronica's life, with her attention shifting from the primacy of her identity as a mother to a rejection of that identity" (43). She also examines how "Veronica's experience with trauma has never been directly addressed and so the subtle undertones of violent sexuality (anticipated or demonstrated) persist because she is unable to confront the potential reality of the abuse" (Curtis, 2015, p. 47). Murazanova (2018) examines how the unspeakable nature of trauma is constructed in narratives by encompassing media, belonging to the audio, visual and textual domains. She discusses three works, namely Kurt Vonnegut's Slaughterhouse-Five (1969), Jonathan Safran Foer's Extremely Loud \& Incredibly Close (2005), and Art Spiegelman's In the Shadow of No Towers (2004) to explore various literary techniques that the writers have employed in order to "represent the unspeakable and evasive nature of traumatic experiences" (Murazanova, 2018, p. 2). Murazanova, through a close reading of these texts, finds that the writers have used literary techniques like fragmentation, syntax disruption, ellipses, text/image layout, repetitions, symbols, photograph insertion and assimilation, intertexts, framing of panels, and so on to represent trauma. She explores how "intermediality," the merging of different media plays a crucial role in the three works (Murazanova, 2018 , p. 2). She also analyses "intermediality" as an intertextual dimension that produces multiple voices and perspectives from which traumatic experiences are depicted and viewed (Murazanova, 2018, p. 2). At the outset, she discusses the key concepts in trauma theory, drawing on works by Freud (1961), Felman \& Laub (1992), Caruth (1996), and Herman (1997). These trauma theorists believe that "traumatic events exist outside of time structures because they are not directly assimilated into memory and hence evade understanding and framing as experiences that are located in the past" (Murazanova, 2018, p. 68). They also believe that trauma belatedly returns in the form of flashbacks, nightmares, and traumatic re-enactment that are to be re-experienced in the 
present. She holds the discussion of the three novels to explore the historical traumas of the bombing of Dresden by allied forces in 1945 and the terrorist attacks of 2001 both in content and form. It is found that the writers of these novels, Vonnegut and Spiegelman in Slaughterhouse-Five (1969) and In the Shadow of No Towers (2004) respectively present the "fractured sense of self" (68). Spiegelman (1969) does so by switching pronouns and also by depicting himself as an old cartoon character. Then she goes on to examine the fragmentary and disruptive nature of trauma which is conveyed by the use of intertexts. She observes that "Vonnegut uses entries from history books, bits of songs and snippets of prayers". Foer and Spiegelman adopt "literary intertexts" as well as "photographs as literary companions to depict the unspeakable" (Murazanova, 2018, p. 69). Reworkings of Drew's and Owerko's photographs of the people falling from the towers allow the narrators to illustrate visually how traumatic events impact them. It also conveys the disruptive and unspeakable nature of trauma. Murazanova (2018) argues that the "intermediality of text and image in the three works disrupts the linearity and chronology of the narratives due to the insertion of decontextualized images..." (Murazanova, 2018, p. 69). She comes to the opinion that the incorporation of visual elements helps the reader to decode and reassemble into a whole, allowing him or her, through active reading, to witness the protagonist's working through of trauma. She analyses various literary techniques: fragmentation, syntax disruption, ellipses, text/image layout, repetitions, symbols, photograph insertion and assimilation, intertexts, framing of panels, and so on in order to represent the unspeakable and evasive nature of traumatic experiences.

\section{Findings}

The researches reviewed have discussed diverse traumatic experiences and explored different ways of their representation. Olive (2014) examines the impact that both trauma studies and postcolonial literature can have upon one another. In the end, the research looks forward to the future inclusion of trauma studies within postcolonial literary criticism. Seran (2015) examines the "inadequacy of Western trauma theory to account for and provide healing to Indigenous victims and to give satisfactory results according to Indigenous, as opposed to Western, criteria..." (Seran, 2015, p. 668). She argues that postcolonial literary criticism can complement trauma theory to tackle indigenous issues by paving the way for "communal life-writing" and exploration of the "postmemory of subsequent generations" (Seran, 2015, p. 670). Tembo (2017) argues that "the literary construction of the post-genocide Rwandan state is so much bound with historical and stereotypical labels that propagated hate memories in the build-up. Narrative strategies like transgenerational empathy, intermediality of text and image, using fragmentation, syntax disruption, ellipses, text/image layout, repetitions, symbols, photograph insertion and assimilation, intertexts, framing of panels, inter-textuality, repetition and fragmentation, and flashback have been employed by the researchers to deal with the challenges of representation.

\section{Conclusion and Recommendation}

The above researches in a way or other focuses on literary techniques, but all such techniques are not enough to fully address the complexities of traumatic experiences and the issues of representation. Besides, looking into how trauma studies draw on postcolonialism and post-modernism, researchers can also consider the significance of narrative theory. This paper recommends that the narrative features and techniques embedded in the narratives can be utilized for the representation and understanding of diverse traumatic experiences. The narrative components like plot (event), character and theme can be analyzed to discuss the psychological trauma of different characters. researches can also rely on narrative techniques like flashbacks, flashforward, frame story, events in parallel, narrative shift, multi-perspectivity, repetitive designation, epiphany, amplification, imagery, tone, use of repetitive sentence structure, hamartia, peripetia, and comparison to examine how these techniques help represent the psychological trauma of the characters in the narratives.

\section{References}

[1] Caruth, C. (1996). Unclaimed Experience: Trauma, Narrative, and History. Johns Hopkins University Press.

[2] Curtis, K. (2015). The Narrative of Traumatic Memory in Postcolonial Irish Fiction. Thesis, BSU, Virtual Commons, vc.bridgew.edu/theses/28.

[3] Daukšaitè, A. (2013). Means of Representation of Traumatic Experience in Trauma Fiction and Vladas Kalvaitis' Sustiprintorežimobarakas. European Academic Research, I (9). 2544-2559. euacademic.org/UploadArticle/186.pdf.

[4] De-Mey, L. (2012). The Representation of Trauma in Shira Nayman's Awake in the Dark and The Listener. Thesis, Ghent University, shiranayman.com/wp-content/uploads/2020/01/TraumaRepresentedinShiraNaymansAwakeinTheDarkandTheListener LiseDeMey.pdf.

[5] Durrant, S. (2012). Surviving Time: Trauma, Tragedy, and the Postcolonial Novel. Journal of Literature and Trauma Studies, 1 (1). $95-117$. www.researchgate.net/publication/236817809 Surviving Time Trauma Tragedy and the Postcolonial Novel.

[6] Finck, S. (2006). Reading Trauma in Postmodern and Postcolonial Literature: Charlotte Delbo, Toni Morrison, and the Literary Imagination of the Aftermath. Ph.D. Thesis, Louisiana State $\mathrm{U}$ and Agricultural and Mechanical C.

http://digitalcommons.Isu.edu/gradschool dissertations/1804.

[7] Heidarizadeha, N. (2015). The Significant Role of Trauma in Literature and Psychoanalysis. Procedia - Social and Behavioral Sciences. 192, 788 - 95. core.ac.uk/download/pdf/82780838.pdf.

[8] Hussain, S. (2018). Confusion and Trauma Suffered by Women during Partition: A Study of Selected Short Stories. Research Review: International Journal of Multidisciplinary, 3 (8). (pp. 585-89). rrjournals.com/wp-content/uploads/2018/08/585-589 RRIJM180308108.pdf.

[9] Karpasitis, S. (2011). Awake, Arise, or Be Forever Fallen: Satan's Post-traumatic Recovery in Milton's Paradise Lost. International Journal of the Humanities9 (5). www.academia.edu/1798969/Awake Arise or be Forever Fallen Satans Post-

traumatic Recovery in Miltons Paradise Lost. 
[10] Kidd, K. B. (2005). A is for Auschwitz: Psychoanalysis, Trauma Theory, and the Children's Literature of Atrocity. Children's Literature, Johns Hopkins UP., 33 (1). 120-149. Project MUSE, muse.jhu.edu/journals/chl/summary/v033/33.1 kidd.html.

[11] Long, Z. C. (2012). Toward an Early Modern Theory of Trauma: Conscience in"Richard III". Journal of Literature and Trauma Studies, University of Nebraska P., 1(1). 49-72. Project MUSE, muse.jhu.edu/article/477618/summary.

[12] Marder, E. (2006). Trauma and literary studies: Some enabling questions. Reading on: Trauma, memory, and testimony. 1 (1). 1-6. readingon.library.emory.edu/issue1/iss1toc.htm.

[13] Murazanova, A. (2018). The Representation of Trauma through Intermediality in Slaughterhouse-Five, Extremely Loud \& Incredibly Close and In the Shadow of No Towers. Thesis, University of Leiden, Leiden university repository, hdl.handle.net/1887/62777.

[14] Olive, J (2014). Postcolonial Trauma Narratives: Traumatic Historiography and Identity in Amitav Ghosh's The Calcutta Chromosome. Thesis, Georgia State University. scholarworks.gsu.edu/english theses/170.

[15] Perring, C. (2013). Childhood Trauma in Memoir and Fiction: Blame, Anger and Forgiveness, and the Role of Mental Illness. Is This culture of Trauma?, edited by Michael Bick and Jessica Aliaga Lavrijsen, Interdisciplinary-Net. 13-21.

[16] Rogers, N. (2004). The Representation of Trauma in Narrative: A Study of Six Late Twentieth Century Novels, Doctoral Dissertation, University of Warwick. Pugwash. lib.Warwick. ac.UK/record=b2083733 S15.

[17] Seran, J. (2015). Australian Aboriginal Memoir and Memory: A Stolen Generations Trauma Narrative. Humanities, edited by Sonya Andermahr, University of Edinburgh, 4 (4). 661-675 doi.org/10.3390/h4040661.

[18] Tal, K. (1995). Worlds of Hurt: Reading the Literatures of Trauma, Cambridge University Press.

[19] Ward, L. (2008). Holocaust Memory in Contemporary Narratives: Towards a Theory of Transgenerational Empathy. Ph.D. Thesis, U. of Exeter. ore.Exeter.ac.UK/repository/handle/10036/47273.

[20] Whitehead, A. (2011). Trauma Fiction. Edinburgh University Press. 